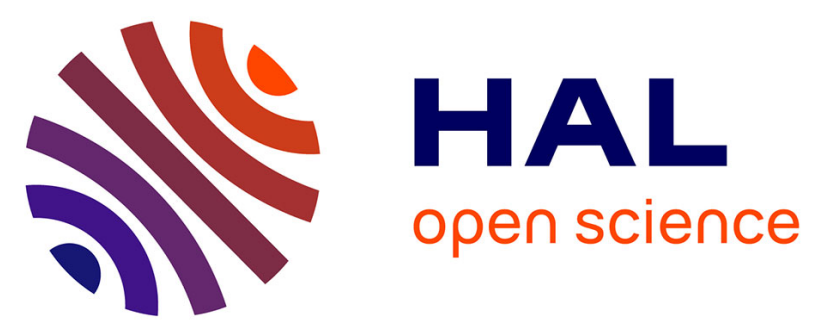

\title{
Sulfamethazine removal by means of a combined process coupling an oxidation pretreatment and activated sludge culture - preliminary results
}

Imen Saidi, Florence Fourcade, Didier Floner, Isabelle Soutrel, Nizar

Bellakhal, Abdeltif Amrane, Florence Geneste

\section{To cite this version:}

Imen Saidi, Florence Fourcade, Didier Floner, Isabelle Soutrel, Nizar Bellakhal, et al.. Sulfamethazine removal by means of a combined process coupling an oxidation pretreatment and activated sludge culture - preliminary results. Environmental Technology, 2017, 38 (21), pp.2684-2690. 10.1080/09593330.2016.1273395 . hal-01558363

HAL Id: hal-01558363

https://hal-univ-rennes1.archives-ouvertes.fr/hal-01558363

Submitted on 7 Jul 2017

HAL is a multi-disciplinary open access archive for the deposit and dissemination of scientific research documents, whether they are published or not. The documents may come from teaching and research institutions in France or abroad, or from public or private research centers.
L'archive ouverte pluridisciplinaire HAL, est destinée au dépôt et à la diffusion de documents scientifiques de niveau recherche, publiés ou non, émanant des établissements d'enseignement et de recherche français ou étrangers, des laboratoires publics ou privés. 
Sulfamethazine removal by means of a combined process coupling an oxidation pretreatment and activated sludge culture - Preliminary results

Imen Saidi $^{1,3,4}$, Florence Fourcade ${ }^{1,2,4}$, Didier Floner ${ }^{1,4}$, Isabelle Soutrel ${ }^{1,2,4}$, Nizar Bellakhal ${ }^{3}$, Abdeltif Amrane ${ }^{* 1,2,4}$, Florence Geneste ${ }^{* 1}$

1) Institut des Sciences Chimiques de Rennes, Université de Rennes 1, UMR-CNRS 6226, Campus de Beaulieu, 35042 Rennes Cedex, France.

2) Ecole Nationale Supérieure de Chimie de Rennes Université de Rennes 1, UMR-CNRS 6226, 11 allée de Beaulieu, CS 50837, 35042 Renne Cedex 7, France.

3) Unité de recherche de Catalyse d'Electrochimie de Nanomatériaux et leurs applications et de didactique CENAD, Institut National des Sciences Appliquées et de Technologie (INSAT), B.P.N ${ }^{\circ} 676,1080$ Tunis Cedex, Tunisie.

4) Université Européenne de Bretagne, 5 boulevard Laënnec, 35000, France

* Corresponding authors. Tel. +33 223235965; Fax. +33 223236939. E-mail address:

Florence.Geneste@univ-rennes1.fr (F. Geneste), Abdeltif.Amrane@univ-rennes1.fr $($ A.

Amrane) 


\section{Abstract}

A coupled electrochemical process and biological treatment was used to remove a biorecalcitrant antibiotic: sulfamethazine (SMT). The pre-treatment was performed in a homemade flow cell involving graphite felt as a working electrode at potentials of 1 and 1.6 V/SCE; it was followed by a biological process involving activated sludge purchased from a local wastewater treatment plant. Activated sludge cultures of pretreated and non-pretreated sulfamethazine solution were carried out for 3 weeks, and different parameters were monitored, especially TOC and SMT concentration. HPLC results revealed that the target molecule was not assimilated by activated sludge. However, and confirming the improvement previously observed for the $\mathrm{BOD}_{5} / \mathrm{COD}$ ratio, from 0.08 before electrolysis to 0.58 after electrolysis, a pre-treatment step in oxidation at $1.6 \mathrm{~V} / \mathrm{SCE}$ led to a fast decrease of TOC during the subsequent biological treatment, since the mineralization yields increased from $10 \%$ for a non-pretreated SMT solution to $76.6 \%$ after electrolysis in oxidation (1.6 V/SCE), confirming the efficiency of coupling electro-oxidation process with a biological treatment for the mineralization of sulfamethazine. Moreover, when the electrolysis was performed at 1 V/SCE, no biodegradation was observed, underlining the importance of the electrochemical pretreatment.

Keywords: sulfamethazine; electro-oxidation pretreatment; activated sludge; biological treatment; combined process.

\section{Introduction}

Sulfamethazine (SMT) (Fig. 1) is an antibiotic that belongs to the pharmaceutically important group of heterocyclic sulfonamides. It is widely used in medicine and veterinary practice as an antibacterial drug in pharmaceutical preparations [1]. 
Special attention is given to the treatment of waters contaminated with sulfonamides, which are not efficiently degraded in sewage treatment plants and are therefore transferred into water bodies [2]. Sulfamethazine is mentioned as the predominant sulfonamide found in livestock animal wastewater and a very emerging pollutant continuously delivered into waters bodies. It has attracted growing attention due to its recalcitrant behavior in the environment [3].

A variety of technologies have been developed to effectively remove this emerging pollutant and especially antibiotics, such as sorption on goethite [4], biological methods [5] photolysis [3,6,7] photo-catalysis with $\mathrm{TiO}_{2}$ and $\mathrm{ZnO}$ as catalysts $[1,8,9]$, anodic oxidation [10], photoFenton [2,11], Electro-Fenton [12] and photoelectro-Fenton processes [13] as well as other coupled processes [14-16]. Among these technologies, physical methods consist only in a transfer of the target compounds from water to a solid phase without any degradation. Although biological processes are economically interesting, they are not effective for antibiotics removal due to their high toxicity and resistance [2,14,17]. Several Advanced Oxidation Processes have demonstrated to be effective for the removal of sulfamethazine. These methods often lead to a total effluent mineralization but in this case they appear expensive. In some cases and according to the duration of treatment, they also favor the production of a great variety of by-products because of their absence of selectivity. From this, the combination of such physico-chemical processes to a biological treatment can appear relevant and have been previously recommended [18-25]; in this connection electrochemical processes have been recently tested to improve biodegradability of solution containing organic recalcitrant compounds including sulfamethazine [14,16,26,27], which were then treated by activated sludge cultures to complete the mineralization of the solutions and hence achieve the treatment [15,18,28-31]. Regarding the pretreatment step, advanced electrochemical oxidation process, namely electro-Fenton $[14,15]$ or direct electrochemical oxidation [16] have been considered and showed promising results. Indeed, for $0.2 \mathrm{M}$ initial 
SMT concentration and in the optimal electro-Fenton pretreatment conditions, mineralization yields of $61.4,78.8$ and $93.9 \%$ were obtained during the biological treatment for SMT solutions pretreated during $0.5,1$ and $4 \mathrm{~h} \mathrm{[15].}$

In the case of direct electrochemical SMT oxidation, the impact of the pretreatment on biodegradability was previously assessed [16]. The pre-treatment was achieved in an electrochemical flow cell using a graphite felt electrode of high specific surface area. Under optimal conditions, the biodegradability based on the $\mathrm{BOD}_{5}$ on $\mathrm{COD}$ ratio measurement was improved from 0.08 initially to 0.58 after electrolysis [16], namely above the threshold limit value $(0.4)[20,32]$. However, this positive impact of the electrochemical pretreatment was not confirmed by a subsequent biological treatment. Therefore, to confirm the relevance of the proposed combined process for sulfamethazine, treatment should be assessed; this task was the main purpose of this paper.

\section{Materials and Methods}

\subsection{Chemicals and materials}

Sulfamethazine (purity 99\%) was obtained from Alfa Aesar (Schiltigheim, France). Inert supporting electrolyte $\mathrm{Na}_{2} \mathrm{SO}_{4}$ (purity 99\%) was purchased from Carlo Erba Reactif-SDS Acetonitrile (purity 99.9\%) was HPLC grade obtained from Sigma-Aldrich (Saint-Quentin Fallavier, France). Graphite felt (RVG 4000) was supplied by Mersen (Paris La Defense). Its specific area measured by the BET method, its volume density and its carbon content were $0.7 \mathrm{~m}^{2} \mathrm{~g}^{-1}, 0.088 \mathrm{~g} \mathrm{~cm}^{-3}$ and $99.9 \%$, respectively.

\subsection{Materials for the electrochemical pre-treatment}

Electrochemical pre-treatment, in continuous system, was performed in a home-made flow cell [26]. Two interconnected PAPYEX carbon papers supplied by Mersen (France) were used as counter-electrodes $(85 \mathrm{~mm} \times 85 \mathrm{~mm})$ and compartments were separated by cationic 
exchange membranes (Ionac 3470 - Lanxess SAS, Courbevoie, France). The reference electrode (Saturated Calomel Electrode - SCE) was positioned in the middle of the graphite felt (48 mm diameter and $12 \mathrm{~mm}$ width) and the potential control was performed using a potentiostat. To ensure a good homogeneity of the potential distribution in the three dimensional working electrode, the felt was located between the two counter-electrodes [33]. The cell was thoroughly rinsed with distilled water before and after each experiment. The solution $\left(50 \mathrm{mg} \mathrm{L}^{-1}\right.$ sulfamethazine in $\left.0.1 \mathrm{M} \mathrm{Na}_{2} \mathrm{SO}_{4}\right)$ percolated the porous electrode at various flow rates monitored by a Gilson minipuls 2 peristaltic pump (Middleton, WI, USA).

\subsection{Biological treatment}

Activated sludge obtained from a local wastewater treatment plant (Beaurade, Rennes, France) was used in this study. It was washed at least five times with water and centrifuged at $3000 \mathrm{rpm}$ for $10 \mathrm{~min}$ to remove any residual carbon and mineral source. Cultures were at least carried out in duplicates at $25{ }^{\circ} \mathrm{C}$ in $250 \mathrm{~mL}$ erlenmeyers flasks containing $100 \mathrm{~mL}$ of medium with $0.5 \mathrm{~g} \mathrm{~L}^{-1}$ of activated sludge. The following mineral basis was used for all experiments $(\mathrm{g}$ $\left.\mathrm{L}^{-1}\right): \mathrm{Na}_{2} \mathrm{HPO}_{4} 2 \mathrm{H}_{2} \mathrm{O}, 33.4 ; \mathrm{KH}_{2} \mathrm{PO}_{4}, 8.5 ; \mathrm{K}_{2} \mathrm{HPO}_{4}, 20.8 ; \mathrm{MgSO}_{4} .7 \mathrm{H}_{2} \mathrm{O}, 22.5 ; \mathrm{CaCl}_{2}, 27.6$; $\mathrm{FeCl}_{3}, 0.26$ and $\mathrm{NH}_{4} \mathrm{Cl}, 7510^{-3}$. The $\mathrm{pH}$ was then adjusted to 7.0 with $\mathrm{NaOH}$ solution. Samples $(5 \mathrm{~mL})$ were taken every 2 or 3 days and filtered on $0.45 \mu \mathrm{m}$.

\subsection{Analytical Procedures}

\subsubsection{High Performance Liquid Chromatography (HPLC)}

The residual sulfamethazine concentration was determined by HPLC using a Waters 996 system equipped with waters 996 PDA (Photodiode Array Detector) and Waters 600 LCD Pump. The separation was achieved on a Waters C-18 $(5 \mu \mathrm{m} ; 4.6 \times 250 \mathrm{~mm})$ reversed-phase and the mobile phase consisted of a mixture of acetonitrile/ultra-pure water $(35 / 65, \mathrm{v} / \mathrm{v})$ delivered at a flow rate of $1 \mathrm{~mL} / \mathrm{min}$. Detection of sulfamethazine was carried out at $268 \mathrm{~nm}$ and the retention time was approximately $5 \mathrm{~min}$. 


\subsubsection{Liquid chromatography-mass spectrometry (UPLC-MS/MS)}

2.4.2.1. Ultra-pressure liquid chromatography.

The analytes were separated by a Waters Acquity UPLC system (Waters Corporation, Milford, MA, USA) consisting of an Acquity UPLC binary solvent manager, an Acquity UPLC sample manager and an Acquity UPLC column heater equipped with a Waters Acquity UPLC BEH C18 column (2.1 mm x $100 \mathrm{~mm}, 1.7 \mu \mathrm{m}$ particle size) (Milford, MA, USA)) maintained at $45^{\circ} \mathrm{C}$. Isocratic LC elution was performed with $0.1 \%$ formic acid in acetonitrile as mobile phase $\mathrm{A}$ and an ultrapure water

9.5:0.5 acetonitrile $(\mathrm{v} / \mathrm{v})$ mix, with added $0.1 \%(\mathrm{v} / \mathrm{v})$ of formic acid as mobile phase B. Separation of the analytes on the column was performed with a mobile phase consisting of a mixture of phase A/phase $\mathrm{B}(5 / 95, \mathrm{v} / \mathrm{v})$ delivered at a flow rate of $0.4 \mathrm{~mL} \mathrm{~min}{ }^{-1}$.

\subsubsection{2. andem mass spectrometry.}

The separated compounds were detected with a Waters Micromass Quattro Premier (Waters Corporation, Manchester, UK) triple quadrupole mass spectrometer. It was operated with an electrospray source in positive ionization mode with a cone potential of $40 \mathrm{~V}$. The ionization source conditions were: capillary voltage of $3.0 \mathrm{kV}$, source temperature of $120^{\circ} \mathrm{C}$ and desolvation temperature of $350^{\circ} \mathrm{C}$. The cone and desolvation gas flows were $50 \mathrm{~L} \mathrm{~h}^{-1}$ and 750 $\mathrm{L} \mathrm{h}^{-1}$, respectively; they were obtained from an in-house nitrogen source. High-purity argon (99.99\%, Air Liquid, Paris, France) was used as collision gas and was regulated at $0.1 \mathrm{~mL}$ $\min ^{-1}$. Analyses were performed in full scan and daughter scan modes. Spectra were acquired between 50 and $300 \mathrm{~m} / \mathrm{z}$ and the data were treated with Micromass Mass-Lynx 4.1 software.

\subsubsection{Total Organic Carbon (TOC) measurements}

The solutions were filtered on Sartorius Stedim Minisart $0.40 \mu \mathrm{m}$ GF prefilters (Goettingen, Germany). TOC was measured by means of a TOC- $\mathrm{V}_{\mathrm{CPH} / \mathrm{CPN}}$ Total Organic Analyzer Schimadzu. Organic carbon compounds were combusted and converted to $\mathrm{CO}_{2}$, which was 
detected and measured by a non-dispersive infrared detector (NDIR). Reproducible TOC values were always obtained using the standard NPOC (Non Purgeable Organic Carbon) method. For each sample, each measurement was triplicated.

\subsubsection{Chemical Oxygen Demand (COD) measurements}

Chemical Oxygen Demand was measured by means of a Test Nanocolor ${ }^{\circledR}$ CSB 160 and 300 from Macherey-Nagel (Düren, Germany). The amount of oxygen required for the oxidation of the organic and mineral matter at $164^{\circ} \mathrm{C}$ for $30 \mathrm{~min}$ was quantified after oxidation with $\mathrm{K}_{2} \mathrm{Cr}_{2} \mathrm{O}_{7}$ at acidic $\mathrm{pH}$ and heating.

\subsubsection{Biological Oxygen Demand $\left(\mathrm{BOD}_{5}\right)$ measurements}

Biodegradability was deduced from $\mathrm{BOD}_{5}$ measurements, as previously reported [16].

\section{Results and discussion}

\subsection{Electrochemical pretreatment prior to biological treatment}

Electrochemical oxidation of sulfamethazine on carbon felt was previously investigated [12] and showed an enhancement of the biodegradability of sulfamethazine solution after electrolysis. The electrochemical behavior of sulfamethazine $\left(50 \mathrm{mg} \mathrm{L}^{-1}\right)$ was first studied in neutral salts $\left(\mathrm{Na}_{2} \mathrm{SO}_{4} 0.1 \mathrm{~mol} \mathrm{~L} \mathrm{~L}^{-1}\right)$ by cyclic voltammetry on a glassy carbon electrode, showing an electroactivity in oxidation $(1 \mathrm{~V} / \mathrm{SCE})$. The pre-treatment was then carried out using an electrochemical flow cell with a graphite felt electrode as working electrode at 1 and 1.6 V/SCE. After only a single pass through the cell, the analysis of the electrolyzed solution showed high degradation yield (more than 90\%) while mineralization remained limited (it did not exceed 23\%). The influence of different parameters such as the flow rate and the applied potential on the degradation of the molecule and the biodegradability of by-products was examined. As presented in table 1 and in agreement with previous results [16], the $\mathrm{BOD}_{5} / \mathrm{COD}$ ratio increased from 0.08 before electrolysis to 0.58 after electrolysis. To confirm 
these promising results, a biological treatment should be assessed out to check the biodegradability improvement after pretreatment.

\subsection{Biological treatment}

In order to confirm the encouraging results obtained after electrochemical pretreatment [16], biological treatment on activated sludge of pure sulfamethazine solution and electrolyzed solution at $1 \mathrm{~V}$ and $1.6 \mathrm{~V}$ were carried out.

\subsubsection{Biosorption}

Prior, to the biological treatment, biosorption on activated sludge of SMT and by-products from SMT oxidation should be assessed. Given that, sorption is a rapid mechanism which take only few hours, TOC and residual SMT concentrations were monitored during the first 2 hours of activated sludge culture on pure SMT and the electrolyzed solutions (E=1 V and 1.6 $\mathrm{V}$, flow rate of $1 \mathrm{~mL} \mathrm{~min}^{-1}$ ).

As displayed in Fig. 2, neither SMT nor its by-products appeared significantly biosorbed on activated sludge, owing to the observed stability of TOC values and the residual SMT concentrations.

From these results, no significant involvement of biosorption of the target compound SMT or its degradation products of electrolysis have to be considered during the biological treatment, and hence any decrease of the SMT amount and the TOC values can be attributed to biodegradation.

Based on a review of the related literature, biosorption of organic compounds depends on various factors (molecular size, degree of ionization, solubility, charge, hydrophobicity [34].

Yang et al. [35] investigated the biosorption of sulfonamide antibiotics (sulfamethoxazole, sulfadimethoxine, sulfamonomethoxine) onto activated sludge. They found that the sorption phenomenon depended on the molecular structure. Indeed, after $2 \mathrm{~h}$ of contact, 7, 12 and 
$18.7 \%$ of sulfamethoxazole, sulfamonomethoxine and sulfadimethoxine were respectively biosorbed at $\mathrm{pH} 7$, for 2.56 g.L $\mathrm{L}^{-1}$ of activated sludge. The differences observed were mainly due to the structure of the pyrimidinic ring and biosorption was the weakest for sulfamethoxazole, the closest structure to that of sulfamethazine.

Biosorption depends also on $\mathrm{pH}[36]$ and weaker biosorption was observed when sulfonamide antibiotics were in their anionic form. pKa of sulfamethazine are 2.07 and 7.65 ; in our biological operating conditions (neutral $\mathrm{pH}$ ), a non-negligible part of sulfamethazine was therefore in an anionic form, which is not in favor of biosorption. Moreover, in neutral $\mathrm{pH}$ conditions, sulfamethazine responded to a low biodegradability and a weak biosorption [37].

The absence of significant biosorption of SMT on activated sludge experimentally observed was therefore in accordance with all these literature data.

\subsubsection{SMT Biodegradation}

Biological treatments were carried out in aerobic conditions and somes parameters, SMT concentration and TOC, were monitored during the 18 days of culture; samples were regularly taken and were duplicated in order to check the reproducibility of the results.

Time-course of SMT concentration during the biological treatment did not show significant removal, since low degradation yield were recorded: $3.4 \pm 1.8 \%$ after 18 days (Fig. 2). TOC evolution (Fig. 3) confirmed the non-biodegradability of the target compound in these culture conditions, since it remained nearly constant during the biological treatment of non pretreated SMT, the mineralization yield was close to 5\% after 18 days. This result was in good agreement with the low value obtained for the $\mathrm{BOD}_{5} / \mathrm{COD}$ ratio $(0.08)$ [16] and with previous results recorded during the treatment of sulfamethazine by means of a combined process coupling an electro-Fenton pretreatment with a biological treatment [15], which also observed an absence of biodegradability of sulfamethazine, owing to the nearly constant TOC values obtained during 20 days of activated sludge culture. 


\subsubsection{Biodegradation of the electrolyzed solution}

After only a single pass through the electrochemical flow cell the electrolyzed solution ( $E=1$ $\mathrm{V}$ and $1.6 \mathrm{~V}$, flow rate of $1 \mathrm{~mL} \mathrm{~min}^{-1}$ ) was collected for a subsequent biological treatment.

As observed in Fig. 4, no really significant TOC decrease was measured during culture for SMT solution oxidized at 1 V/SCE; only nearly $5 \%$ of the carbon was mineralized after 18 days, indicating an almost total absence of biodegradability of the by-product resulting from oxidation (1 V/SCE). This result was in agreement with the only low increase of the $\mathrm{BOD}_{5} / \mathrm{COD}$ ratio values after the oxidation $(1 \mathrm{~V} / \mathrm{SCE})$ step, from 0.08 initialy to 0.14 after electrolysis (Table 1).

Contrarily, a significant reduction of the TOC was obtained for the SMT solution oxidized at 1.6 V/SCE during activated sludge culture, $72.3 \pm 1.3 \%$ TOC removal was measured after 18 days, confirming the increase of the $\mathrm{BOD}_{5} / \mathrm{COD}$ ratio, since a value of 0.58 was obtained after electrolysis at 1.6 V/SCE (Table 1). Oxidation at $1.6 \mathrm{~V} / \mathrm{SCE}$ led therefore to the formation of some by-products readily biodegradable. From this, an overall mineralization yield of 79.3\% was obtained after the biological treatment of SMT previously oxidized at 1.6 V/SCE.

The main intermediates identified after the sulfamethazine pretreatment were 2-hydroxy-4,6dimethylpyrimidine, 2-Amino-4,6-dimethylpyrimidine, 4-((4,6-dimethyl-2-pyrimidinyl)amino)phenol and $N$-(4-aminophenyl)-4,6 dimethyl-2-pyrimidinamine (Table 2).

If we compare the solutions electrolyzed at $1 \mathrm{~V}$ and $1.6 \mathrm{~V}, 2$-hydroxy-4,6-dimethylpyrimidine was not detected at $1.6 \mathrm{~V}$. 2-Amino-4,6-dimethylpyrimidine and $\mathrm{N}$-(4-aminophenyl )-4,6 dimethyl-2-pyrimidinamine are less concentrated at $1.6 \mathrm{~V}$ while the amount of 4-((4,6dimethyl-2-pyrimidinyl)-amino)phenol was similar in the two electrolyzed solutions.

Pyrimethanil [38] is a pesticide that is known to interfere with the secretion of fungal enzymes that are necessary for infection by pathogens. Its chemical structure is close to $N$-(4- 
aminophenyl)-4,6 dimethyl-2-pyrimidinamine except the presence of an amino group in the aromatic ring.

Few microorganisms are able to metabolize pyrimidine: Pseudomonas aeruginosa [39] and Saccharomyces kluyveri [40]. Escherichia coli K-12 can grow on pyrimidine compounds and metabolize them as sole nitrogen source by means of Rut (pyrimidine utilization) pathway composed of seven proteins. This pathway enzymes can cleave the pyrimidine ring but with the production of reactive and toxic intermediates [41].

Moreover, in anaerobic culture in serum bottles, pyrimidine was partially biodegraded to methane and carbon dioxide by soil microorganisms but the degradation needed around one year to reach $83 \%$ with initial concentration near $350 \mu \mathrm{M}$ [42].

Finally, Cambon et al. [43] have observed in their study the accumulation of 2-amino-4,6dimethylpyrimidine in same amount in both sterile and non sterile soil. They concluded on the slight biodegradation of the target compound with less than $10.4 \%$ of removal in non sterile soil.

All these studies showed that pyrimidinamine and pyridimine derivatives are not easily biodegradable and the present results seem to suggest that their concentration in the electrolyzed solution is a key factor for biodegradability.

When an electro-Fenton pretreatment was carried out prior to a biological treatment [15], the evolution of biodegradability did not show similar trend. Indeed, after an electro-Fenton pretreatment, an acclimation of the sludge to the byproducts was observed, owing to the constant TOC values observed until 10 days of culture, and a clear decrease then occurred until total mineralization (97.3\%); while after direct oxidation on the carbon felt, a rapid TOC decrease was observed during activated sludge culture. This shows that even if total target compound degradation and low mineralization yields were observed for both pretreatments, and even if some similarities were found between degradation products, the degradation 
pathway involved in direct oxidation on the carbon felt electrode (this work) and in electrochemical advanced oxidation process, electro-Fenton [15], were not the same. It was most likely the consequence of differences in the amounts of by-products and/or the formation of other unidentified by-products.

\section{Conclusion}

This study demonstrated the efficiency of coupling an electrochemical oxidation with a biological treatment for enhancing the mineralization of sulfamethazine, a sulfonamide drug. Pre-treatments in oxidation were performed in a home-made flow cell at 1 and 1.6 V/ESC on graphite felt. Preliminary tests showed an increase of the biodegradability with the oxidation potential, the $\mathrm{BOD}_{5} / \mathrm{COD}$ ratio increased from 0.08 before electrolysis to 0.14 and 0.58 after electrolysis in oxidation at 1 and $1.6 \mathrm{~V} / \mathrm{SCE}$ respectively, namely above the limit of biodegradability for the highest potential. This enhancement of biodegradability was confirmed during biological treatment, since $79.3 \%$ of total organic carbon (TOC) was removed by means of the combined process, namely after biological treatment of a solution electrolyzed at 1.6 V/SCE. In order to try to reduce the working potential on the one hand and to improve mineralization during the biological process on the other hand, an acclimation of the activated sludge to the degradation products resulting from electrolysis could be subsequently investigated. 


\section{References}

[1] Kaniou S, Pitarakis K, Barlagianni I, Poulios I. Photocatalytic oxidation of Sulfamethazine. Chemosphere. 2005; 60:372-380.

[2] Liu Y, Hu J, Wang J. Fe ${ }^{2+}$ enhancing sulfamethazine degradation in aqueous solution by gamma irradiation Radiat Phys Chem. 2014; 96:81-87.

[3] Batista APS, Pires FCC, Teixeira ACSC. The role of reactive oxygen species in sulfamethazine degradation using UV-based technologies and products identification. J Photochem Photobiol A-Chem. 2014; 290:77-85.

[4] Guo X, Yang C, Dang Z, Zhang Q, Li Y, Meng Q. Sorption thermodynamics and kinetics properties of tylosin and sulfamethazine on goethite. Chem Eng J. 2013; 223:59-67.

[5] Pérez S, Eichhorn P, Aga DS. Evaluating the biodegradability of sulfamethazine, sulfamethoxazole, sulfathiazole and trimethoprim at different stages of sewage treatment. Environ Toxicol Chem. 2005; 24:1361-1367.

[6] Liu Y, Wang J. Degradation of sulfamethazine by gamme irradiation in the presence of hydrogen peroxide. J Hazard Mater. 2013; 250-251:99-105.

[7] Gao Y, Gao N, Deng Y, Yang Y, Ma Y. Ultraviolet UV light-activated persulfate oxidation of sulfametazine in water. Chem Eng J. 2012; 195:248-253.

[8] Chebli D, Fourcade F, Brosillon S, Nacef S, Amrane A. Integration of photocatalysis and biological treatment for azo dye removal - application to AR183. Environ Technol. $2011 ; 32: 507-514$.

[9] Khenniche L, Favier L, Bouzaza A, Fourcade F, Aissani F, Amrane A. Photocatalytic degradation of bezacryl yellow in batch reactors - feasibility of the combination of photocatalysis and a biological treatment. Environ Technol. 2015; 36:1-10.

[10] Cheng W, Yang M, Xie Y, Fang Z, Nan J, Tsang PE. Electrochemical degradation of the antibiotic in aqueous solution by the Ti/SnO2-Sb-Ce anode. Environ Technol. 2013; 34:2977-2987.

[11] Perez-Moya M, Graells M, Castells G, Amigo J, Ortega E, Buhigas G, Pérez LM, Mansilla HD. Charaterization of the degradation performance of the sulfamethazine antibiotic by photo-Fenton process. Water Res. 2010; 44:2533-2540.

[12] Yahya MS, El Karban M, Oturan N, El Kacemi K, Oturan MA. Mineralization of the antibiotic levofloxacin in aqueous medium by electro-Fenton process: kinetics and intermediates products analysis. Environ Technol. 2016; 37:1276-1287. 
[13] El-Ghenymy A, Rodriguez RM, Arias C, Centellas F, Garrido JA, Cabot PL, Brillas E. Electro-Fenton and Photoelectro-Fenton degradation of the antimicrobial sulfamethazine using a boron-doped diamond anode and an air-diffusion cathode. $\mathbf{J}$ Electroanal Chem. 2013; 701:7-13.

[14] Mansour D, Fourcade F, Bellakhal N, Dachraoui M, Hauchard D, Amrane A. Biodegradability improvement of sulfamethazine solutions by means of an electroFenton process. Water Air Soil Pollut. 2012; 223:2023-2034.

[15] Mansour D, Fourcade F, Huguet S, Soutrel I, Bellakhal N, Dachraoui M, Hauchard D, Amrane A. Improvement of the activated sludge treatment by its combination with electro-Fenton for the mineralization of sulfamethazine. Int Biodeter Biodegrad. 2014; 88:29-36.

[16] Saidi I, Soutrel I, Fourcade F, Amrane A, Floner D, Bellakhal N, Geneste F. Flow electrolysis on high surface electrode for biodegradability enhancement of sulfamethazine solutions. J Electroanal Chem. 2013; 707:122-128.

[17] Lodha B, Chaudhari S. Optimization of Fenton-biological treatment scheme for the treatment of aqueous dye solutions. J Hazard Mater. 2007; 148:459-466.

[18] Yahiat S, Fourcade F, Brosillon S, Amrane A. Photocatalysis as a pretreatment prior to a biological degradation of cyproconazole. Desalination. 2011; 281:61-67.

[19] Scott JP, Ollis DF. Integration of chemical and biological processes for water treatment: Review and recommendations. Environ Prog. 1995; 14:88-103.

[20] Pulgarin C, Invernizzi M, Parra S, Sarria V, Polania R, Peringer P. Strategy for the coupling of photochemical and biological flow reactors useful in mineralization of biorecalcitrant industrial pollutants. Catal Today. 1999; 54:341-352.

[21] Farré MJ, Brosillon S, Domènech X, Peral J. Evaluation of the intermediates generated during the degradation of Diuron and Linuron herbicides by the photo-Fenton reaction. J Photochem Photobiol A-Chem. 2007; 189:364-373.

[22] Yahiaoui I, Aissani-Benissad F, Fourcade F, Amrane A. Removal of a mixture tetracycline-tylosin from water based on anodic oxidation on a glassy carbon electrode coupled to activated sludge. Environ Technol. 2015; 36:1837-1846.

[23] Gómez C, Rodriguez J, Freer J, Lizama C, Zaror C, Mansilla HD. Coupling of Photocatalytic and Biological Reactors to Remove EDTA-Fe from Aqueous Solution. Environ Technol. 2007; 28:123-127.

[24] Sarathy SR, Stefan MI, Royce A, Mohseni M. Pilot-scale UV/ $\mathrm{H}_{2} \mathrm{O}_{2}$ advanced oxidation process for surface water treatment and downstream biological treatment: effects on 
natural organic matter characteristics and DBP formation potential. Environ Technol. 2011; 32:1709-1718.

[25] Oviedo C, Contreras D, Freer J, Rodríguez J. Fe(III)-EDTA Complex Abatement Using a Catechol Driven Fenton Reaction Combined with A Biological Treatment. Environ Technol. 2004; 25:801-807.

[26] Fontmorin JM, Huguet S, Fourcade F, Floner D, Geneste F, Amrane A. Electrochemical oxidation of 2,4-D: analysis of by-products and Improvement of the biodegradability. Chem Eng J. 2012; 195-196:208-217.

[27] Belkheiri D, Fourcade F, Geneste F, Floner D, Aït-Amar H, Amrane A. Feasibility of an electrochemical pre-treatment prior to a biological treatment for tetracycline removal. Sep Purif Technol. 2011; 83:151-156.

[28] Ferrag-Siagh F, Fourcade F, Soutrel I, Aït-Amar H, Djelal H, Amrane A. Tetracycline degradation and mineralization by the coupling of an electro-Fenton pretreatment and a biological process. J Chem Technol Biotechnol. 2013; 88:1380-1386.

[29] Yahiaoui I, Aissani-Benissad F, Fourcade F, Amrane A. Removal of tetracycline hydrochloride from water based on direct anodic oxidation $\left(\mathrm{Pb} / \mathrm{PbO}_{2}\right.$ electrode) coupled to activated sludge culture. Chem Eng J. 2013; 221:418-425.

[30] Alonso-Salles N, Fourcade F, Geneste F, Floner D, Amrane A. Relevance of an electrochemical process prior to a biological treatment for the removal of an organophosphorous pesticide, phosmet. J Hazard Mater. 2010; 181:617-623.

[31] Fontmorin JM, Huguet S, Fourcade F, Geneste F, Floner D, Amrane A. Coupling of an electrochemical process with a biological treatment for the removal of 2,4Dichlorophenoxyacetic acid. Biochem Eng J. 2013; 70:17-22.

[32] Sarria V, Parra S, Adler N, Peringer P, Benitez N, Pulgarin C. Recent developments in the coupling of photoassisted and aerobic biological processes for the treatment of biorecalcitrant compounds. Catal Today. 2002; 76:301-315.

[33] Moinet C. Electrosynthèse organique en continu. Méthodes directes et indirectes. Journal de Physique IV. 1994; 4:175-184.

[34] Zhang Y, Wei D, Huang R, Yang M, Zhang S, Dou X, Wang D, Vimonses V. Binding mechanisms and QSAR modeling of aromatic pollutant biosorption on Penicillium oxalicum biomass. Chem Eng J. 2011; 166:624-630.

[35] Yang S-F, Lin C-F, Wu C-J, Ng K-K, Lin AY-C, Hong P-KA. Fate of sulfonamide antibiotics in contact with activated sludge - Sorption and biodegradation. Water Res. 2012; 46:1301-1308. 
[36] Yang S-F, Lin C-F, Lin AY-C, Hong P-KA. Sorption and biodegradation of sulfonamide antibiotics by activated sludge: Experimental assessment using batch data obtained under aerobic conditions. Water Res. 2011; 45:3389-3397.

[37] Yu T-H, Lin AY-C, Panchangam SC, Hong P-KA, Yang P-Y, Lin C-F. Biodegradation and bio-sorption of antibiotics and non-steroidal anti-inflammatory drugs using immobilized cell process. Chemosphere. 2011; 84:1216-1222.

[38] Errami M, Salghi R, Zarrouk A, Assouag M, Zarrok H, Benali O, Bazzi E, Hammouti B, Al-Deyab SS. Electrochemical degradation of imazalil and pyrimethanil by anodic oxidation on boron-doped diamond. J Chem Pharm Res. 2012; 4:3518-3525.

[39] Kim S, West TP. Pyrimidine catabolism in Pseudomonas aeruginosa. FEMS Microbiol Lett. 1991; 77:175-180.

[40] Beck H, Dobritzsch D, Piskur J. Saccharomyces kluyveri as a model organism to study pyrimidine degradation. FEMS Yeast Res. 2008; 8:1209-1213.

[41] Kim K-S, Pelton JG, Inwood WB, Andersen U, Kustu S, Wemmer DE. The Rut Pathway for Pyrimidine Degradation: Novel Chemistry and Toxicity Problems. J Bacteriol. 2010; 192:4089-4102.

[42] Adrian NR, Suflita JM. Anaerobic biodegradation of halogenated and compounds in aquifer slurries nonhalogenated N-, S-, and O-heterocyclic compounds in aquifer slurries. Environ Toxicol Chem. 1994; 13:1551-1557.

[43] Cambon J-P, Zheng SQ, Gerap JB. Dégradation chimique ou microbiologique des sulfonylurées dans le sol. I. Cas du sulfbméturon méthyle. Weed Res. 1992; 32:1-7. 
Table 1: Impact of the applied potential on the biodegradability and the mineralization of the electrolyzed solutions [16]. Electrolysis conditions: [SMT] $]_{0}=50 \mathrm{mg} \mathrm{L}^{-1}, 1 \mathrm{~mL} \mathrm{~min}^{-1}$.

\begin{tabular}{ccc}
\hline Applied potential $(\mathbf{V})$ & BOD $_{\mathbf{5}} / \mathbf{C O D}^{\mathrm{a}}$ & TOC $^{\mathbf{m}}$ \\
& & \\
\hline- & $0.08 \pm 0.01$ & $23.2 \pm 1.3$ \\
$\mathbf{1}$ & $0.14 \pm 0.00$ & $18.0 \pm 2.7$ \\
$\mathbf{1 . 6}$ & $0.58 \pm 0.10$ & $20.0 \pm 2.1$ \\
\hline
\end{tabular}

${ }^{\mathrm{a}}$ Uncertainties are based on two reproducibility measurements

Table 2: Intermediates products formed during the electrochemical oxidation of sulfamethazine [16]. Electrolysis performed at 1V/SCE, at a flow rate of $1 \mathrm{~mL}$ min-1, with an initial sulfamethazine concentration of $50 \mathrm{mg} \mathrm{L}-1$, and $0.1 \mathrm{M} \mathrm{Na} \mathrm{SO}_{4}$.

2-hydroxy-4,6-dimethylpyrimidine




\section{Figure legends}

Fig.1. Chemical structure of sulfamethazine.

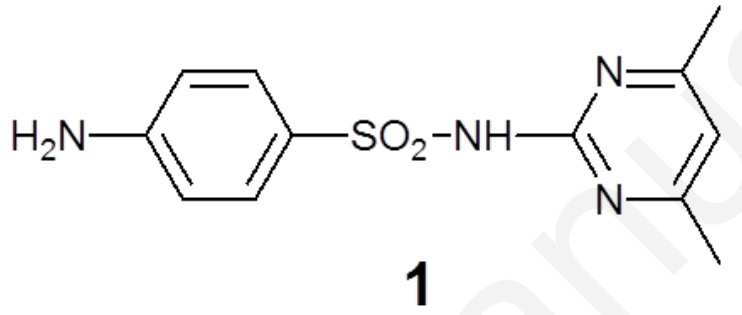


Fig. 2. Time-courses of the residual SMT concentrations $\left({ }^{---^{--}}\right)$and the TOC values of SMT $\left(-^{-}\right)$, and SMT solutions oxidized at $1 \mathrm{~V}\left(--^{-}\right)$and $1.6 \mathrm{~V}\left(\right.$ - $\left.^{-\cdot}\right)$ during biosorption on activated sludge $\left(0.5 \mathrm{~g} \mathrm{~L}^{-1}\right)$ Error $\pm 2 \%$ is based on 3 measurements.

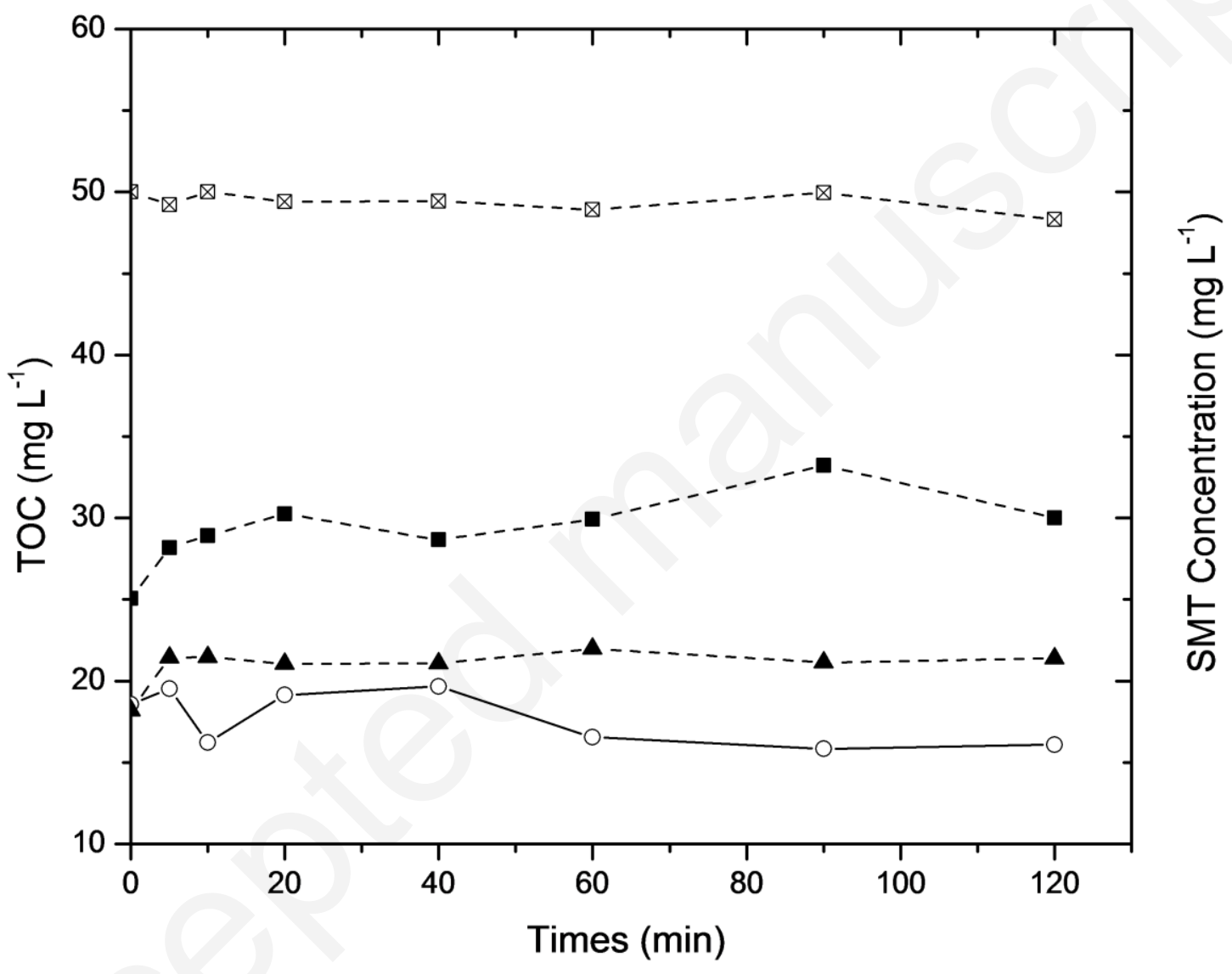


Fig. 3. Time-course of non-pretreated SMT $\left(50 \mathrm{mg} \mathrm{L}^{-1}\right)$ during activated sludge culture $(0.5 \mathrm{~g}$ $\left.\mathrm{L}^{-1}\right)$.

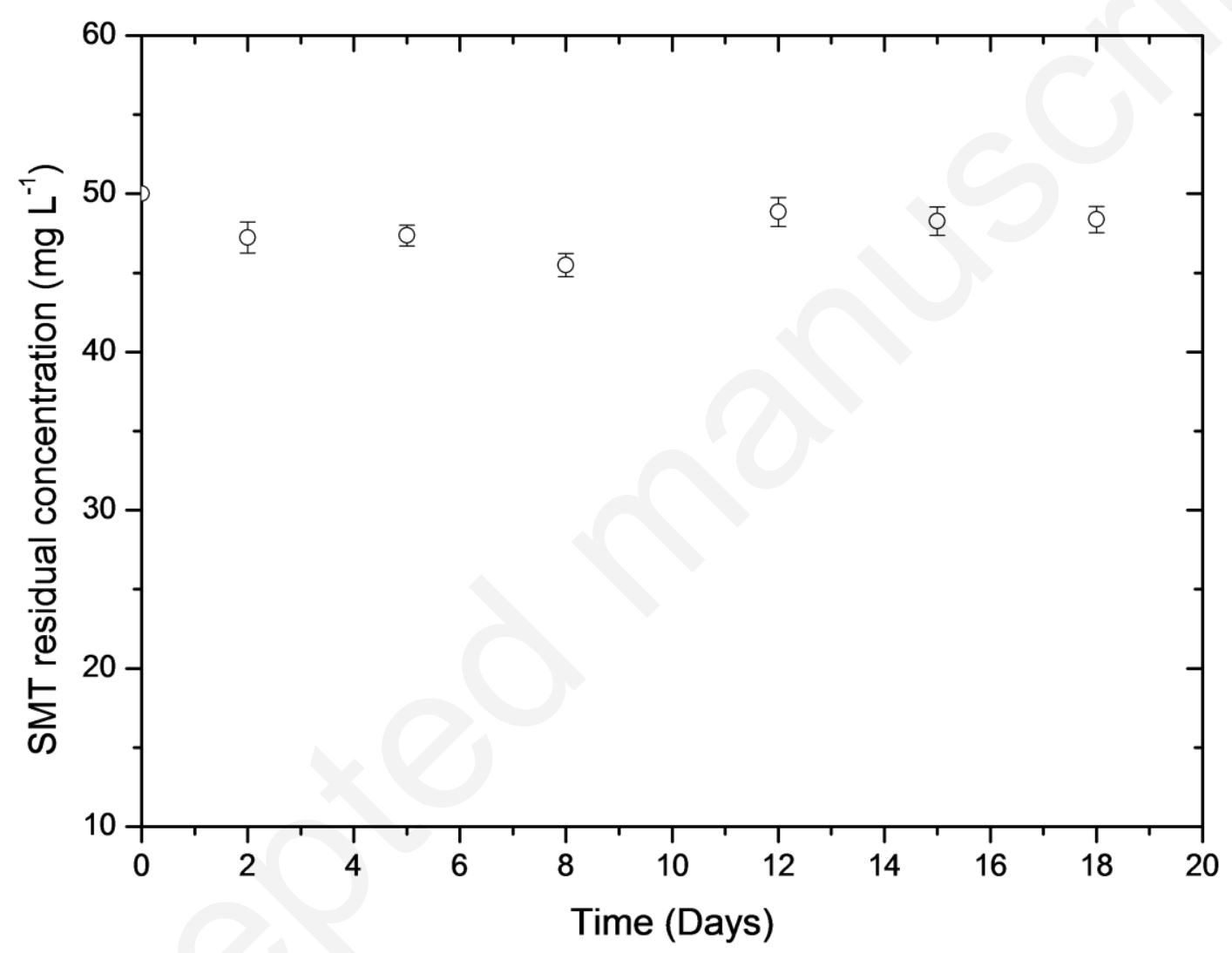


Fig. 4. TOC/TOC ${ }_{0}$ time-courses during activated sludge culture $\left(0.5 \mathrm{~g} \mathrm{~L}^{-1}\right)$ of SMT $\left(50 \mathrm{mg} \mathrm{L}^{-}\right.$ $\left.{ }^{1}\right)(\boldsymbol{\square})$, and SMT solutions oxidized at $1 \mathrm{~V}\left({ }^{\circ}\right)$ and $1.6 \mathrm{~V}\left({ }^{\triangle}\right)$.



